\title{
Animating the Carbon Cycle
}

\author{
Oswald J. Schmitz ${ }^{*}$, Peter A. Raymond ${ }^{1}$, James A. Estes ${ }^{2}$, Werner A. Kurz ${ }^{3}$, \\ Gordon W. Holtgrieve ${ }^{4}$, Mark E. Ritchie ${ }^{5}$, Daniel E. Schindler ${ }^{4}$, Amanda C. Spivak ${ }^{6}$, \\ Rod W. Wilson ${ }^{7}$, Mark A. Bradford ${ }^{1}$, Villy Christensen ${ }^{8}$, Linda Deegan $^{9}$, Victor Smetacek $^{10}$, \\ Michael J. Vanni ${ }^{11}$, and Christopher C. Wilmers ${ }^{12}$. \\ ${ }^{1}$ School of Forestry and Environmental Studies, Yale University, New Haven, CT 06511 USA, \\ ${ }^{2}$ Department of Ecology and Evolutionary Biology, University of California Santa Cruz, CA \\ 95064 USA, ${ }^{3}$ Natural Resources Canada, Canadian Forest Service, Victoria, British Columbia, \\ Canada V8Z 1M5, ${ }^{4}$ School of Aquatic and Fishery Sciences, University of Washington, Seattle, \\ WA 98195-5020 USA, ${ }^{5}$ Department of Biology, Syracuse University, Syracuse, NY 13244 USA, \\ ${ }^{6}$ Marine Chemistry and Geochemistry Department, Woods Hole Oceanographic Institution, \\ Woods Hole, MA 02543-1050 USA, ${ }^{7}$ Biosciences, College of Life and Environmental Sciences, \\ University of Exeter, Exeter, EX4 4QD UK, ${ }^{8}$ Fisheries Centre, University of British Columbia, \\ Vancouver, BC Canada V6T 1Z4, ${ }^{9}$ The Ecosystems Center Marine Biological Laboratory, Woods \\ Hole, MA 02543 USA, ${ }^{10}$ Alfred Wegener Institute for Polar and Marine Research, 27570 \\ Bremerhaven, Germany, ${ }^{11}$ Department of Biology and Ecology, Evolution and Environmental \\ Biology Graduate Program, Miami University, Oxford, Ohio 45056 USA, ${ }^{12}$ Environmental \\ Studies Department, University of California, Santa Cruz, California 95064 USA
}

Electronic supplementary material: The online version of this article (doi: ) contains supplementary material, which is available to authorized users.

Author Contributions. All authors discussed the concepts and contributed to writing the manuscript.

Correspondence author; e-mail: oswald.schmitz@yale.edu

\section{ACCEPTED FOR PUBLICATION IN ECOSYSTEMS}




\begin{abstract}
Understanding the biogeochemical processes regulating carbon cycling is central to mitigating atmospheric $\mathrm{CO}_{2}$ emissions. The role of living organisms has been accounted for, but the focus has traditionally been on contributions of plants and microbes. We develop the case that fully "animating" the carbon cycle requires broader consideration of the functional role of animals in mediating biogeochemical processes and quantification of their effects on carbon storage and exchange among terrestrial and aquatic reservoirs and the atmosphere. To encourage more hypothesis-driven experimental research that quantifies animal effects we discuss the mechanisms by which animals may affect carbon exchanges and storage within and among ecosystems and the atmosphere. We illustrate how those mechanisms lead to multiplier effects whose magnitudes may rival those of more traditional carbon storage and exchange rate estimates currently used in the carbon budget. Many animal species are already directly managed. Thus improved quantitative understanding of their influence on carbon budgets may create opportunity for management and policy to identify and implement new options for mitigating $\mathrm{CO}_{2}$ release at regional scales.
\end{abstract}

Key words: animal mediation of carbon cycling; animal multiplier effects; animal management for carbon storage; biogeochemical cycling; regional carbon budgets

\title{
INTRODUCTION
}

Over the past several decades, scientists and policy makers have studied the accumulation of atmospheric carbon dioxide $\left(\mathrm{CO}_{2}\right)$ out of concern that humans are altering the dynamics of the global climate system (Revell and Suess 1957; Woodwell and others 1978; Broecker and others 1979; Post and others 1990; Falkowski and others 2000; Sarmineto and Gruber 2007; Houghton 2007). Understanding the processes that determine carbon exchange and storage is central to this undertaking because they determine the quantity of emitted $\mathrm{CO}_{2}$ and its fate among reservoirs within aquatic and terrestrial ecosystems and the atmosphere (Falkowski and others 2000; Sarmineto and Gruber 2007; Houghton 2007). Accounting of the distribution and exchange of carbon among the various reservoirs shows that aquatic and terrestrial ecosystems provide important services because biogeochemical processes within them remove as much as half of the $\mathrm{CO}_{2}$ emitted to the atmosphere each year from anthropogenic activities (Falkowski and others 2000; LeQuéré and others 2009; Ballantyne and others 2012). Although estimates of global-scale carbon storage and exchange among terrestrial and aquatic reservoirs and the atmosphere have continuously been refined (Falkowski and others 2000; LeQuéré and others 2009; Ballantyne and others 2012), large discrepancies still remain between the potential and observed carbon uptake of terrestrial and aquatic reservoirs (Ballantyne and others 2012). This is because understanding of the mechanisms that affect the processes of carbon exchange and storage and their quantification is still incomplete (Falkowski and others 2000; Mahecha and others 2010; Ballantyne and others 2012). Resolving those mechanisms not only provides an acid test of our predictive understanding of Earth as a system (Falkowski and others 2000), but also provides insights needed to formulate actionable policy aimed at mitigating $\mathrm{CO}_{2}$ build-up in the atmosphere (Falkowski et al. 2000; Houghton 2007). 
We develop the case that there may be much profit in quantifying the role of animals in mediating carbon dynamics to further refine estimates of carbon exchange and storage. While mechanisms accounting for the role of animals in biogeochemical processes in general, and the carbon cycle specifically, are becoming better understood (Vanni 2002; Schmitz and others 2010), the magnitude of their effects remains remain poorly quantified. This is in part due to a research tradition in animal community ecology that focuses on biotic interactions among organisms with limited consideration of the link to biogeochemical cycling. It also stems from a classic view in ecosystem ecology that the existence of trophic pyramids of species abundances in ecosystems means that animal species, which occupy higher trophic levels in ecosystems, ought to contribute little to whole ecosystem functioning because (a) inputs of plant-derived materials for biogeochemical cycling overwhelm biomass inputs from all trophic levels, and (b) the order of magnitude lower biomass representation of animals in ecosystems relative to plants and microbes means that they can only have a minor effect on whole ecosystem metabolism (production, elemental cycling, and respiration). Finally, it results from the difficulty in modeling animal effects at the global scale because individual animal species are not globally distributed. Efforts that have attempted a global accounting focus on carbon released directly from animals to the atmosphere through respiration and eructation. The magnitudes of these direct contributions are found to be minuscule when compared to the orders of magnitude larger amounts of carbon released from plants and microbes, even when considering the global release of $\sim 95-120 \mathrm{Tg} \mathrm{yr}^{-1}$ of the potent greenhouse gas methane $\left(\mathrm{CH}_{4}\right)$ by domestic and wild ruminants and termites (Dlugokencky and others 2011). However, such accounting overlooks the pivotal indirect role animals may play in mediating biogeochemical processes. Such indirect effects can cause animals to have disproportionately large impacts on rates and amounts of carbon uptake, storage and release relative to their biomass representation in ecosystems (Fig. 1).

We present quantitative evidence to illustrate the kinds of contributions that animals can make (Table 1). To encourage further quantification of animal effects we highlight some of the known mechanisms by which animals may affect the amounts of carbon taken up, released and transported within ecosystems. While it continues to be challenging to include animals at the global scale, we develop the thesis that an improved understanding of the influence of animals on carbon exchange and storage can and should nonetheless be done for regional scales, given that is the scale at which many carbon management projects are occurring.

\section{CONTEXT FOR CONSIDERING ANIMAL EFFECTS ON CARBON CYCLING}

Most animal species are not globally distributed but instead interact within and across the boundaries of ecosystems. Thus, a refined accounting of animal effects needs to be conducted at the associated regional scales of ecosystems, rather than at a global scale. This focal scale is also consistent with recent calls to pay more attention to regional-scale exchange and storage processes when considering the global carbon budget (Ballantyne and others 2012). Moreover, policies and management to mitigate atmospheric $\mathrm{CO}_{2}$ buildup are usually implemented regionally within sub-national political jurisdictions such as states or provinces (Dulal and others 2012; Venter and Koh 2012).

Huge quantities of carbon currently reside in non-reactive or protected carbon reservoirs following $\mathrm{CO}_{2}$ uptake by photosynthesis and then burial of the plant biomass in soils, peatlands or aquatic sediments (Tarnocai and others 2009; Schuur and Abbott 2011). Animals can mediate 
many physical, chemical and biological processes within ecosystems (Fig. 1) that determine how much carbon is fixed, transformed and transported among those carbon reservoirs. This has the potential to cause regional ecosystems to shift from being net $\mathrm{CO}_{2}$ sinks to sources, or vice versa (Table 1).

Long-term build-up of protected organic carbon requires only a fraction of organic matter to escape microbial, plant and detritivore metabolism through transfer to a more biologically inert soil, sediment, or deep ocean reservoir. For example, carbon is sequestered in deep ocean waters as dissolved inorganic carbon (DIC), either through direct transport of DIC to these depths via deep-water formation or through the decay of organic matter delivered there from the euphotic zone. Animals can affect the production of inorganic carbon that is then transported to depth via physical processes (Fig. 1). Once in any of these storage pools, carbon remains a potential source of $\mathrm{CO}_{2}$ and $\mathrm{CH}_{4}$ release through biotic (microbial, bioturbation) or abiotic (e.g., fires influencing terrestrial pools, thawing of permafrost) disturbances (Kurz and others 2008; Houghton and others 2009; Schuur and Abbott 2011).

\section{Animal Effects on Regional Carbon Flux Magnitudes}

Several studies are beginning to document that animal impacts can be large enough to be included in regional assessments. Especially noteworthy is the Arctic, where $\sim 500 \mathrm{Pg}$ of carbon is currently bound up in organic carbon-rich permafrost known as yedoma (Zimov and others 2006). Large migrating mammalian grazers like caribou, muskoxen, horses, and bison can maintain the grasslands that have a high albedo and also reduce winter snow insulation through trampling that, depending on animal densities, could reduce permafrost temperatures and offset warming (Zimov and others 2009). But, declines of these vast herds can trigger large-scale shifts in the vegetation community. As grazer populations dwindle the grasslands that helped maintain the permafrost transform to mosses and shrubs leading to a growing risk of peat decomposition. The sustained annual $\mathrm{CO}_{2}$ and $\mathrm{CH}_{4}$ release from this $10^{6} \mathrm{~km}^{2}$ region to the atmosphere, at the low end of the estimate (Table 1; see Appendix A in Supplemental Material), is equivalent to $10 \%$ of the fossilfuel carbon emissions from China or USA. At the high end of the estimate, carbon release could rival annual emissions from China and USA and exceed Russia's emissions by a factor of four (Fig. 2). Modeling indicates that the reestablishment of abundant grazing herds could lead to carbon storage in these regions on the scale of tens of $\mathrm{kg} \mathrm{C} \mathrm{m}^{-2}$ under certain scenarios (Zimov and others 2009).

Other ecosystems may also depend on large grazers to maintain carbon sinks. Prior to the 1960s migrating wildebeest in the Serengeti-Mara grassland-savanna system in East Africa were decimated by disease and poaching, greatly reducing their numbers from about 1.2 million animals to 300,000 (Holdo and others 2009). Following the population reduction, ungrazed grasslands accumulated large amounts of above-ground organic matter fuel and consequently $80 \%$ of the ecosystem (grasslands and savanna woodlands) burned annually by wildfire, leading to a net release of carbon to the atmosphere as $\mathrm{CO}_{2}$. Over many years this state change also led to the loss of organic carbon from soil carbon stocks. Wildebeest population recovery, due to disease management and anti-poaching enforcement, reversed the spatial extent of the wildfires: every increase of 100,000 animals translates into $~ 10 \%$ less area burned (Holdo and others 2009). This shift in fire regime arose because grazers effectively divert a fraction of carbon from combustible aboveground standing biomass to dung that is incorporated by insect detritivores into 
soil reservoirs not prone to burning. The current grazing regime is estimated to have restored the Serengeti as a net $\mathrm{CO}_{2}$ sink by facilitating pumping of atmospheric carbon back into soil reservoirs and in savanna tree regrowth (Table 1; see Appendix A in Supplemental Material). Without this sink, carbon released from the Serengeti would equal East Africa's current annual fossil fuel carbon emissions (Fig. 2).

The boreal forest biome is a reservoir for 30\% of terrestrial carbon (Houghton and others 2009; Pan and others 2011). Both vertebrate and invertebrate species within these systems may be instrumental drivers of biogeochemical processes (Pastor and others 1988; Dymond and others 2010). The moose is a dominant mammalian herbivore whose geographic range distribution is conterminous with the North American boreal forest. Experimental research has shown that moose can indirectly control rates of primary productivity and heterotrophic respiration of boreal ecosystems through selective browsing and by priming soil microbial decomposition. Moose do this by altering the release of nutrients for plant production through changes in the nutrient (carbon and nitrogen) content of litter and their dung (Pastor and others 1988; see Appendix A in Supplemental Material). Experimentation revealed that the influence of moose through these pathways leads to an inverse relationship between moose density and ecosystem uptake of $\mathrm{CO}_{2}$ in net primary production (NPP) and plant standing biomass. High moose densities can cause declines in $\mathrm{CO}_{2}$ uptake and storage in boreal ecosystems by altering the physical environment through direct browsing on photosynthetic tissue and indirectly through reduction of tree growth that leads to reductions in forest canopy height and closure. Canopy reductions of $12 \%$ to $50 \%$ can result in lower humidity, warmer and drier soils. This leads to lower net productivity of boreal ecosystems and creates biophysical conditions that are more conducive to forest fires (Schmitz and others 2003). Management to keep moose populations in lower abundances $(\sim 0.5$ $\mathrm{km}^{-2}$ vs. 1-1.5 $\mathrm{km}^{-2}$ ) across the entire North American boreal region, after accounting for $\mathrm{CO}_{2}$ released via moose and microbial respiration (see Appendix A in Supplemental Material), could lead, conservatively, to an estimated NPP of approximately $548-656 \mathrm{Tg} \mathrm{C} \mathrm{yr}^{-1}$ at high moose densities to approximately $689-722 \mathrm{Tg} \mathrm{C} \mathrm{yr}^{-1}$ at lower moose densities (see Appendix A in Supplemental Material). The net difference in NPP between higher and lower moose densities is equivalent to approximately $42 \%$ to $95 \%$ of all of Canada's (globally, the $8^{\text {th }}$ highest emitter) total annual $\mathrm{CO}_{2}$ release as fossil-fuel emissions (Table 1; see Appendix A in Supplemental Material). Part of this management effort could include ensuring that apex predators such as wolves attain natural levels that maintain moose populations below their carrying capacity.

Insects have also not been explicitly considered in most continental-to-global scale carbon models and budget estimates because, until recently, there was a lack of appreciation of the spatial scale over which impacts may occur or have occurred (Kurz and others 2008b). Insects both defoliators and bark beetles, can alter the carbon budget of ecosystems in outbreak years by consuming and respiring foliage biomass, reducing plant growth, and causing wide-spread plant mortality especially during severe, multi-year outbreak episodes. These die-offs cause large quantities of carbon to be transferred from live biomass to dead organic matter pools from which $\mathrm{CO}_{2}$ is released either through heterotrophic respiration during invertebrate and microbial decomposition, or through wildfires promoted by high fuel loads (Kurz and others 2008b; Dymond and others 2010; Hicke and others 2012). The current climate-change mediated bark beetle outbreak in western North America, especially British Columbia, Canada, is of unprecedented scale. Estimates (Kurz and others 2008a) indicate that the net carbon balance is

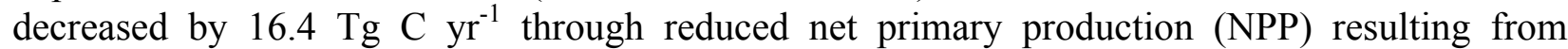
increased beetle-induced tree mortality and increased decomposition losses from killed trees 
(Table 1; see Appendix A in Supplemental Material). This amount is equivalent to British Columbia's current fossil-fuel carbon emissions (Fig. 2). As the outbreak abates, the forest carbon balance is unlikely to recover to its pre-disturbance state for at least 20 years if not more (Kurz and others 2008a). The $\mathrm{CO}_{2}$ impact on the atmosphere over the 21-year period of analysis was estimated at $270 \mathrm{Tg} \mathrm{C}$ (Kurz and others 2008a), about 1.8 times the average annual fossil fuel emissions in Canada over the last decade.

Animals can also be quantitatively important in marine ecosystems, which have stored approximately half of anthropogenic carbon emissions since 1800 (Sabine and others 2004). In particular, the inorganic component of the marine carbon cycle is based on biogenic calcification, i.e., organismal precipitation of carbonate minerals. Their dissolution near the surface ocean is important as it raises alkalinity that enhances absorption of atmospheric $\mathrm{CO}_{2}$ and buffers the effects of ocean acidification. Previously, microscopic plankton, especially coccolithophorids, were considered the only quantitatively important sources. But, fish and echinoderms can be significant contributors to the pelagic and benthic carbonate inventories (Wilson and others 2009; Lebrato and others 2010; Perry and others 2011). Marine teleost fish precipitate carbonates (in the mineral form "high Mg-calcite") within their intestine (Wilson and others 2009) and release these at high rates as a by-product of a variety of physiological processes (Cooper and others 2010; Whittamore and others 2010). Conservative estimates that combine this physiological understanding with recent models of global fish biomass suggest fish calcite production amounts to 40 to $110 \mathrm{Tg} \mathrm{C} \mathrm{yr}^{-1}$ (Table 1; see Appendix A in Supplemental Material). In addition, the global production of $\mathrm{CaCO}_{3}$ by echinoderms (primarily by sea urchins, brittle stars, and sea stars) is estimated (Lebrato and others 2010) to be $102 \mathrm{Tg} \mathrm{C} \mathrm{yr}^{-1}$ across three marine zones (Table 1; see Appendix A in Supplemental Material). The global carbon bound up in calcite produced by each of fish and echinoderms is equivalent to the amount of carbon released in fossil fuel emissions by countries like Brazil, the UK, and Australia (Fig. 2). Fish populations are also highly altered by anthropogenic activities and thus these rates have presumably been altered over past decades.

The biotic component of the marine carbon cycle is typically viewed as involving primarily $\mathrm{CO}_{2}$ uptake by algae. As in terrestrial forest ecosystems, animals can mediate that photosynthetic uptake. For example, coastal kelp forests are recovering in areas along the western seacoast of North America where sea otter numbers are rebounding after being hunted to the brink of extinction. Similar to wolves in the boreal, sea otters indirectly benefit kelp by regulating herbivorous sea urchins, which if left unchecked have devastating grazing impacts on kelp (Wilmers and others 2012). Restoring sea otters to historic densities throughout their $12,000 \mathrm{~km}^{2}$ range, from Vancouver Island to the western edge of the Aleutian Island can lead to a $0.9-1.3 \mathrm{Tg}$ $\mathrm{yr}^{-1}$ increase in NPP, which is equivalent to $6 \%-10 \%$ of the annual carbon released in British Columbia, Canada's fossil-fuel emissions (Fig. 2).

One group of animals that are potentially important to consider but are not discussed at length here are soil fauna. This is because more science is required before their effects on carbon flows are elucidated in a manner that informs detailed management of their populations to achieve net carbon storage. Soil fauna are undoubtedly important in regulating the activities of soil microorganisms (Crowther and others 2012), which are primary agents of both the mineralization and formation of soil organic matter (SOM) (Schmidt and others 2011). This carbon store, to 3-m depth, is approximately triple the size of the atmospheric store (Jobbágy and Jackson 2000) and so management of soil animals has huge potential to mitigate rising atmospheric $\mathrm{CO}_{2}$ concentrations. Yet synthesis of experiments quantifying effects of soil fauna, such as earthworms, on soil carbon stores suggests they may be negligible over the long-term 
even though their short-term activities may promote $\mathrm{CO}_{2}$ emissions by $33 \%$ (Lubbers and others 2013). Further, in an observational study across four European countries and across a gradient of agricultural land use, de Vries and others (2013) showed that earthworm biomass correlated positively with both $\mathrm{CO}_{2}$ emissions and soil carbon contents, highlighting that $\mathrm{CO}_{2}$ fluxes may provide a poor proxy for organismal effects on soil carbon stocks (Conant and others 2011). Clearly, then, soil fauna exert strong controls on carbon fluxes but their effects on carbon stores are uncertain. Changing land management, such as a move toward organic fertilizers, will change the structure of soil food webs by enhancing the abundance of fauna such as earthworms (Lubbers and others 2013), highlighting a need to understand better the net effect of soil fauna on carbon stocks and how these fauna might be managed to promote carbon sequestration.

\section{Compensatory Effects}

Compensatory effects arise when an increase in abundance or process rate of one component of an ecosystem is compensated by a decrease in abundance or process rates of other components, potentially resulting in limited net change in ecosystem structure or functioning. Within animal populations and communities, compensatory effects may arise from feedbacks, such as when animal populations reach abundances where population growth rate declines due to withinpopulation competition for limiting resources or when increases in the abundance of one species causes a decline in another species due to predator-prey or between species competitive interactions. Hence there could be limits on the extent to which management can manipulate animal populations to effect changes in carbon flux and storage because of the interaction between animal population dynamics and ecosystem processes. The magnitudes of these limitations also need to be quantified.

As a case in point, benthic-associated animals influence carbon cycling and fate by consuming deposited organic matter and bioturbating (re-suspending) lake sediments and redistributing nutrients into the water column. These processes mediate the degree of sediment organic carbon uptake into animal biomass and microbial respiration in surface sediments and in re-suspended material in the water column ultimately reducing the amount of carbon buried and protected in sediments (Vanni and others 2011; Knoll and others in review). In some lakes, microbial $\mathrm{CO}_{2}$ release can be counterbalanced by a parallel nutrient cycle involving excretion into the water column of nutrients consumed from benthic detritus. This excretion stimulates algal growth, carbon uptake, and subsequent organic carbon deposition back to the sediments (Vanni and others 2011; Knoll and others in review). Bioturbation effects on carbon fate can be substantial in freshwater lake systems. For instance, approximately $50-60 \%$ of the deposited organic carbon in Ohio reservoirs remains buried, 1-2\% is respired by sediment microbes, $10-$ $15 \%$ is consumed by detritivorous fish (gizzard shad, Dorosoma cepedianum), $25-30 \%$ is directly re-suspended by shad, and 2-3\% is re-suspended by wind (Vanni and others 2011; Knoll and others in review). Simulated reductions in shad population size resulted in relatively modest effects on sediment organic carbon burial. Specifically, lowering shad abundance also lowers fish-driven nutrient cycling and primary production and, thus, algal inputs to the sediments, countering their effects on burial mediated by sediment re-suspension and microbial respiration, described above (Vanni and others 2011; Knoll and others in review).

Compensating effects may also arise from interactions between different ecosystem processes. For example, the build-up of biomass carbon consequent to animal management could be 
vulnerable to other disturbances that could result in carbon being released back to the atmosphere. Boreal forests, which are subject to annual wildfires are especially notable (Kasischke and others 1995) because the carbon released could mitigate any gains in storage due to animals (moose) effects. Wildfires burn $28,000 \mathrm{~km}^{2}$ of Canadian boreal forests annually releasing approximately 1.2-1.6 $\mathrm{kg} \mathrm{C} \mathrm{m}^{-2}$ to the atmosphere (Kasischke and others 1995; Canadian Forest Service 2005). The total estimated release for the entire Canadian boreal region is $0.33-0.44 \mathrm{Tg} \mathrm{C} \mathrm{yr}^{-1}$. But, this is only $\sim 0.2-0.5 \%$ of the additional NPP obtained by managing moose populations. This reinforces the potential value of restoring or managing wolves, which can limit the abundance and distribution of moose and other ungulates, for carbon management (McLaren and Peterson 1994; Ripple and others 2010).

Because outbreaks of bark beetles and defoliating insects tend to be episodic, the large, shortterm release of $\mathrm{CO}_{2}$ following insect outbreaks could presumably be compensated by biomass uptake as the forest ecosystem recovers through new tree growth. However, simulation analysis modeling the aftermath of the British Columbia, Canada pine beetle outbreak, relative to simulated non-outbreak conditions, reveals that recovery is likely to progress very slowly (Kurz

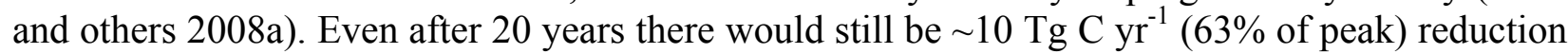
in carbon sinks. The compromised ability of forest ecosystems to be long-term carbon sinks due to episodic insect outbreaks has also been observed in analyses of spruce budworm and gypsy moth outbreaks in Eastern North America (Kurz and others 2008b; Dymond and others 2010; Medvigy and others 2012).

The existence of compensating effects should not, however, become a barrier to future research since compensating effects exist when considering any alteration of biogeochemical cycles and budgets. Thus although we have demonstrated the importance of animals through empirical and experimental evidence, understanding compensating effects will need to become a key part of a complete quantification of the effect of animals on the carbon cycle.

\section{Fluxes vs. Long-term Storage}

If further research demonstrates that animals more broadly can make significant contributions to carbon fluxes, then land and wildlife managers have much potential opportunity to manipulate animal populations in ways that can help mitigate carbon emissions to the atmosphere. But, will such effects be lasting? Estimates suggest that animals could influence long-term carbon storage in terrestrial and aquatic reservoirs.

Management of arctic mammalian grazing herds to maintain permafrost conditions could certainly protect carbon in soils and delay or prevent carbon release from millions of $\mathrm{km}^{2}$ of global arctic regions (Zimov and others 2009). Management of other grazing systems also has long-term storage potential. A majority of the world's grasslands have been degraded by overgrazing or cultivation, and another significant fraction experiences a hyper-frequency of fires and ongoing losses of soil carbon. A simple model of a grassland carbon budget based on insights from the Serengeti grazing system (Ritchie and others in review) suggests that excessive fire or overgrazing can reduce soil carbon stocks by $50-100 \mathrm{Mg} \mathrm{ha}^{-1}$ over a 20-50 year period. Using sustainable grazing practices to recover most of the regionally overgrazed or overburned grasslands and savannas which, at $2.7 \times 10^{9}$ ha, cover more than $10 \%$ of the Earth's land surface (Houghton and others 2009), could theoretically sequester in soils 1-2 Pg of the annual $9 \mathrm{Pg}$ of annual $\mathrm{CO}_{2}$ emissions. While these estimates show promise, an important research priority is to 
provide broader quantitative understanding of the fate of new NPP in terrestrial and aquatic ecosystems attendant to managing animal populations. Clearly, a significant portion of photosynthetically-fixed carbon undoubtedly becomes lost via the fast carbon cycle through plant and animal respiration and microbial decomposition. However some fraction of NPP will evade loss and be stored in plant biomass (Houghton and others 2009), and in soils, deep ocean and coastal sediments (Pastor and others 1988; Wilmers and others 2012).

Quantitative understanding of the implications of animal effects on inorganic carbon production is also needed. In the process of biogenic calcification in seawater, approximately 0.6 moles of $\mathrm{CO}_{2}$ are released for every mole $\mathrm{CaCO}_{3}$ fixed (Ware and others 1992). On human societal timescales, calcification reduces the buffering capacity of the oceans and results in higher atmospheric $\mathrm{CO}_{2}$ concentrations. However, high $\mathrm{Mg}$ calcite produced by fish and echinoderms (Wilson and others 2009; Lebrato and others 2010; Woosley and others 2012) is more prone to rapid dissolution and is thus potentially restores surface ocean alkalinity and $\mathrm{CO}_{2}$ levels compared to carbonates from other sources. There are conflicting data on whether carbonate production by echinoderms will increase or decrease in response to ocean warming and acidification (Lebrato and others 2010), and no data yet on how these combined factors will affect fish carbonate production. It will be important to establish whether these two animal sources will act as negative or positive feedback controls on ocean carbonate chemistry under future climate conditions.

\section{MOVING FORWARD}

\section{Exploring Mechanisms of Animal Effects}

The above examinations of case studies help to demonstrate that animal effects can be quantitatively important within regions. Yet, fully resolving animal effects requires more detailed examinations of mechanisms that link changes in animal abundances with changes in amounts of carbon taken up, released and transported within ecosystems. This requires expanded use of ecosystem experimentation that systematically measures carbon storage and flux between areas where focal animal species abundances vary naturally or are manipulated through experimentation or management (Schmitz and others 2010). Experience shows that such experimentation is possible at spatial scales relevant to management ranging from large fields (Hawlena and Schmitz 2010) to whole lakes (Schindler and others 1997) or terrestrial islands (Pastor and others 1988) to 10's -100's of km² of open-ocean (Smetacek and others 2012). Such efforts have provided fresh insights about the integral role of animals in governing local and regional carbon cycling. Although, some of these studies may circumscribe subsets of species comprising whole ecosystems, we present them here to illustrate the kinds of generalizable and scalable principles about the way animals mediate carbon cycling that can be explored in future research. Broadly speaking, animal mediation of carbon cycling arises when their population abundances change or when their interactions with other species in food webs change.

The cases already presented show that animal-mediated carbon exchange through actions such as significant consumption of plant matter by grazers, pests killing large tracts of live plant biomass, stimulation of decay and microbial decomposition, disturbance, and changes in the physical environment (e.g., snow cover, which affects soil temperature and in northern latitudes permafrost processes), and excretion or production of organic and inorganic compounds that alter 
biogeochemical cycles. Other mediating impacts include disturbing sediments (bioturbation) and translocating nutrients.

Animal mediated nutrient and organic matter transport and translocation is a well-known process in aquatic ecosystems (Vanni 2002). It has also recent been proposed as a major driver of primary production of Amazonian forests. Modeling suggests that extinctions of large bodied animal fauna may have caused up to a $98 \%$ decrease in lateral flow of phosphorus that in turn now exacerbates phosphorus limitation of forest production (Doughty and others 2013). Whales also historically cultivated the ocean by their unique feeding on mesopelagic and deep-water prey such as krill and squid and defecating liquid faeces at the surface, thereby translocating nutrients to surface waters to fuel phytoplankton production (Kanwisher and Ridgway 1983; Nichol and others 2010). Because inorganic iron is highly insoluble in oxic seawater, there can be much more iron within living biomass than in the dissolved phase (Lavery and others 2010). However, the living iron reservoir of Antarctic krill has declined after the great baleen whales were reduced to a small fraction of their historic abundance (Atkinson and others 2004) possibly because largescale recycling of iron was interrupted. Estimates suggest that the 12,000 sperm whales in the Southern Ocean alone could eat $2 \mathrm{Tg}$ of squid in the deep ocean per year, the iron of which when released at the surface would fuel an additional new production of $0.4 \mathrm{Tg} \mathrm{C} \cdot \mathrm{y}^{-1}$ (Atkinson and others 2004). The estimated respiration of these whales is only $0.16 \mathrm{Tg} \mathrm{C} \cdot \mathrm{y}^{-1}$, resulting in a net annual sink of $0.24 \mathrm{Tg} \mathrm{C}$ by this whale pump (Roman and McCarthy 2010). Without predation by surface-defecating whales, the iron in their prey (krill and deep-sea squid) would sink to the deep sea and floor at lower carbon:iron ratios typical of animal carcasses than the higher ratios in plankton in the upper surface pelagic ecosystems maintained by whale fertilization (Roman and McCarthy 2010). Whales can supply other important nutrients to stimulate production and biotic carbon uptake. Based on ammonia concentration in whale faecal plumes, whales in the Gulf of Maine replenish an estimated $0.24 \mathrm{Tg} \cdot \mathrm{y}^{-1}$ of nitrogen to support production, an amount that exceeds the total river input of nitrogen to the gulf (Roman and McCarthy 2010).

Another example is the translocation of organic matter by giant filter-feeding tunicate larvaceans living within the middle depths of the ocean. These filter-feeders consume suspended particles by pumping them through carbon rich mucopolyscaccharide filtering structures that can exceed $60 \mathrm{~mm}$ thickness $\times 1 \mathrm{~m}$ diameter (Robison and others 2005). These structures are discarded regularly (as often as daily) once they become clogged. Discarded structures collapse and sink rapidly to the deep ocean, thereby avoiding microbial decomposition in surface waters (Robison and others 2005). The discarded structures of one species, Bathochordaeus charonalone, alone can account for $5 \%$ of the sinking particulate carbon in the water column above the Monterey Canyon region off of California that eventually reaches $1000 \mathrm{~m}$ depth to become part of long-term (geological time scale) carbon stores (Robison and others 2005). Many freshwater fish and invertebrates also function as nutrient translocators, consuming nutrientcontaining resources in the benthos and excreting dissolved nitrogen and phosphorus into the water column. This stimulates phytoplankton primary production, which can draw $\mathrm{CO}_{2}$ into the water column from the atmosphere, and lead to increased organic carbon burial rates in sediments.

Animals can influence carbon cycling via food web interactions, such as when predators alter the species composition and elemental stoichiometry of entire food webs and storage pools (Schmitz and others 2010). Predators can also cause the induction of physiological changes in their prey that have cascading, multiplier effects on carbon exchange through changes in herbivore impacts on the composition and biomass of plant species, and microbial functioning 
(Schmitz and others 2010). Many insights about food web effects are derived from experiments within mesocosms that control for biophysical conditions such as nutrient supplies and temperatures of the experimental environment to test hypotheses about focal mechanisms. Such studies have revealed that the presence of top predators in artificial experimental streams and ponds has cascading effects on prey and plant abundances. Both vertebrate and invertebrate aquatic predators consistently reduced prey biomass that in turn indirectly increased the abundance of algae (Atwood and others 2013). The enhanced algal abundance due to changes in food web structure led to a $42 \%$ reduction in dissolved $\mathrm{CO}_{2}$ in the water column and a $93 \%$ reduction in $\mathrm{CO}_{2}$ emitted from the mesocosms to the atmosphere (Atwood and others 2013). These cascades are similar to that described for marine kelp forests in the presence and absence of sea otters, providing proof-of-concept for the scalability and generalization of mechanistic insights from small-scale controlled experiments for informing understanding of functioning of regional ecosystems.

There is now growing recognition that the cascading effects of carnivores may also arise through modulation of herbivore foraging impacts (Schmitz and others 2010). In addition to altering total plant abundance available for carbon uptake, herbivory can trigger physiological adjustments in the remaining damaged plants including reduction in photosynthetic rates and increased respiration (Strickland and others 2013). Thus, carnivores could increase plant community carbon fixation and reduce respiration, thereby increasing carbon retention, by causing herbivores to reduce their foraging impacts on plants. This mechanism was demonstrated with a ${ }^{13} \mathrm{CO}_{2}$ pulse-chase field experiment in a grassland ecosystem comprised of herbs and grasses, grasshopper herbivores and spider predators in northeastern Connecticut, USA (Strickland and others 2013). Experimentally manipulating the presence of herbivores and predators in the ecosystem resulted in alteration of fixation of carbon by plants, even without an initial change in total plant or herbivore biomass. Prolonged cascading effects of top predators on plants lead to slowing of carbon loss via ecosystem respiration and reallocation of carbon among plant aboveground and belowground tissues (Strickland and others 2013). As a result, up to 1.4times more carbon was retained in plant biomass when carnivores were present in the experimental ecosystem compared to when they were absent. This outcome was primarily due to greater carbon storage in grass and belowground plant biomass driven largely by reduction in foraging effort of herbivores due to the need to become vigilant and reduce predation risk, rather than a reduction in herbivore abundance due to direct predation (Strickland and others 2013).

The scalability of experiments also provides a basis for understanding greater complexity of natural ecosystems because the biophysical environment can be more variable and the species composition of the food webs can be more diverse. For example, experiments within whole freshwater lake ecosystems have demonstrated that species composition and size structure can control $\mathrm{CO}_{2}$ storage and release, but this varies with nutrient loading (Schindler and others 1997). When planktivorous fish are the top predator in lakes (i.e., with three trophic levels), they control the abundance of large-bodied zooplankton and the remaining small-bodied zooplankton are ineffective at controlling algal production. When piscivorous fish are the top predator (four trophic levels), they suppress the abundance of planktivorous fish, which releases zooplankton from heavy predation (Schindler and others 1997). Consequently, there is a proliferation of largebodied zooplankton grazers that are effective at suppressing algal production. As limiting nutrients are added, primary production increases and the lake can turn from a net carbon source to a carbon sink. At the same nutrient addition, however, lakes with planktivorous top predators can have from 1.2 to 2.9 times higher primary production than lakes with piscivorous top 
predators (Schindler and others 1997). Thus, kind of top predator effect on food web composition can be an important driver of carbon dynamics in lakes, as algae in lakes with planktivorous top predators take up 3.4 to 4.6 times more carbon than in lakes with piscivorous top predators (Schindler and others 1997). The direct management and exploitation of fish in inland waters therefore has likely altered biogeochemical cycles and impacted regional carbon budgets.

Similar effects due to compositional changes within food webs can be inferred for the entire extratropical North Atlantic Ocean region. Environmental warming has resulted in pronounced latitudinal changes in phytoplankton and zooplankton within this region, due to a greater representation of smaller-sized zooplankton (Beaugrand and others 2010). This reorganization of the planktonic food web may influence the fate of carbon in the ocean by shifting the phytoplankton community from diatoms (major exporters of carbon to non-reactive reservoirs in the deep ocean) to coccolithophorid algal species that reside in surface waters. There is also emerging evidence that active management of species such as the North Atlantic cod can alter food web connections and carbon fluxes. The overfishing of cod changes food web composition, especially phytoplankton species composition. This change, coupled with reduced upwelling of nutrient rich water under climate warming, could reduce carbon fluxes into and storage within the marine reservoir not only because of lower nutrient inputs to phytoplankton into the euphotic zone, but also because organic carbon would reside longer in the reactive surface water reservoir (Beaugrand and others 2010).

One of the best representations of animals in current global carbon models is zooplankton in the world's oceans (Falkowski and others 2000). Zooplankton consume large amounts of primary production in the surface ocean and can have direct impacts on algal biomass and carbon fluxes. Zooplankton also have indirect effects because they forage selectively on certain sizes of phytoplankton. This in turn changes the species composition which can affect the rate of aggregate formation, sinking rate, and elemental ratios of exported material and ultimately movement of carbon and nutrients from the reactive surface ocean to non-reactive pools at depth (Smetacek and others 2004). This mechanism of top down control is particularly strong in response to iron enrichment (Smetacek and others 2004).

Traditional concepts of trophic pyramids in terrestrial ecosystems highlight that inputs from plants to soils are more important for regulating belowground processes than inputs from herbivores or predators, because the plant inputs constitute the greatest biomass and carbon flux. Predators are then presumed to regulate ecosystem processes mainly by altering the quality and quantity of plant materials entering soil, via control of herbivore density and foraging behavior (Hawlena and Schmitz 2010). However, the threat of predation can elevate herbivore stress, and consequently metabolism, causing shifts in their body carbon and nitrogen content as herbivores seek out carbohydrate, for energy to fuel heightened metabolism, instead of protein for growth and reproduction (Hawlena and Schmitz 2010). Experiments in field plots within a grassland ecosystem revealed that the threat-induced shift in herbivore body chemistry $(\sim 4 \%$ higher carbon:nitrogen ratio in predator-stressed herbivores) causes up to a 1.25-fold reduction in subsequent mineralization rates of plant-litter inputs. This difference arises because stressed herbivore carcasses were a poorer quality resource, given the lower relative nitrogen content, for soil microbes that use the nitrogen to manufacture enzymes that degrade more recalcitrant plantlitter inputs (Hawlena and others 2012). Predator-induced changes in herbivore body chemistry can thus have surprising multiplier effects on ecosystem carbon cycling by reducing microbialmediated decomposition of plant inputs and hence the rate of $\mathrm{CO}_{2}$ released from the soil (Hawlena and Schmitz 2012). 
Invasive predator species can have large cascading effects on ecosystems via systematic elimination of prey species, in turn reducing potential carbon uptake via ecosystem productivity (Schmitz and others 2010; Estes and others 2011; Wardle and others 2012). This mechanism can be seen operating on islands harboring breeding colonies of seabirds. Seabirds are important vectors of nutrients from the marine realm to terrestrial islands on which they breed. Inorganic nitrogen in seabird guano is vital for terrestrial plant production (Wardle and others 2012). Invasive rats can drive the seabird colonies to local extinction thereby completely eliminating the influx of new guano nutrients and causing a sharp decline in $\mathrm{CO}_{2}$ uptake by lowering island plant production (Wardle and others 2012).

Clearly, the accumulating evidence supports further consideration and quantification of animal effects on ecosystem function through mediation of carbon fluxes. Moreover, animal populations have been and will continue to be altered. The global scale impact of animals still remains difficult to model or assess due to the spatial distribution of animal species, the different natures of animal effects on ecosystem processes in different regions, and currently unexplored quantitative means to scale up local and regional carbon dynamics for accounting in a global budget. At the very least, it is becoming evident that ignoring animal effects at regional scales could result in potential misdiagnosis or mismanagement of factors that determine regional carbon budgets.

\section{INCORPORATING ANIMAL EFFECTS IN CARBON MANAGMENT}

The evidence that we present illustrates how changing animal presence or abundances can alter carbon flux rates as well as the fate of carbon among different reservoirs. In as much as ecosystem management involves deliberate environmental manipulations, we suggest that there is further opportunity to test for animal effects on carbon cycling through experimental management activities that include manipulating animal abundances or presence. In some cases, management to enhance animal presence or abundance is desirable (e.g., enhancing grazer abundances in tundra or grasslands). In other cases, management should avoid having high animal abundances within ecosystems (e.g., herbivorous mammals and insect pests in terrestrial forests, urchins in kelp forests) either through integrated pest management, population harvesting, or ensuring that the trophic structure of ecosystems remains intact by maintaining or restoring predators to ecosystems. The lesson here is that there may be potential for unrealized gains or unintended pitfalls if animal effects are not included in budget calculations on which ecosystem management programs for carbon sequestration are based.

Moreover, policy makers, out of necessity, tend to target energy technology and reductions in energy use to regulate carbon emissions to the atmosphere (Pacala and Socolow 2004; Peters and others 2012). This is an expensive prospect and, for the largest $\mathrm{CO}_{2}$ emitters, requires decade-long alterations in capital investment that have thus far proven insufficient to achieve reductions in global carbon emissions (Peters and others 2012). Further mitigation options are therefore needed, and so there is much value in exploring other means of controlling net emissions via natural sequestration at country or regional-level scales (e.g. carbon emission reduction from deforestation and degradation or REDD+ projects). Ignoring animal effects in such sequestration projects could lead to under- or over-valuation of sequestration potential. Yet, ironically humans already manage populations of many of the animals for other purposes (e.g., fisheries or grazers for food production), so expanding consideration to carbon dynamics would 
not present a radical shift in approach. We show above that there is promise for such management activities to reduce annual release of $\mathrm{CO}_{2}$ to the atmosphere. The magnitudes of effect are on the same order as more established land management activities, such as land conversion to forest. For example, in the United States afforestation and forest aggradation activities aim to sequester $\sim 225$ Tg C $\mathrm{yr}^{-1}$ (USEPA 2013), magnitudes that compare with those of animal effects within forested regions (Table 1). Moreover, many of the examples we present here involve vast regions in which human population densities are low, thereby potentially minimizing conflict between human development goals and management of ecosystem functioning for carbon sequestration.

The regional-scale perspective of animal effects we present here also aligns with the scale of carbon management. REDD+ projects, while negotiated at the global to regional scales, are implemented at scales from the country down to individual land-owners (Dulal and others 2012; Venter and Koh 2012). The 92 UN-certified Clean Development Mechanism (CDM) carbon reforestation or afforestation offset projects (average size of 7,800 ha) collectively cover 7176 $\mathrm{km}^{2}$. One concern about natural carbon management policies is that carbon is sequestered over long time scales but may be lost very quickly following disturbances (Körner 2003). As our case studies demonstrate, animals can cause some of these disturbances and thus drive the rapid loss of carbon. They can also can enhance carbon storage and mitigate release. Therefore management could be much more strategic about including the role of animals in their accounting and thereby control their impacts (Brodie and Gibbs 2009; Tanenzap and Coomes 2012).

There are also trade-offs that need to be reconciled between animal management for carbon mitigation and animal management to protect biodiversity and other ecosystem services (Thomas and others 2013). For example, it is typically held that human activities degrade many services provided by freshwater ecosystems. Eutrophication of lakes and coastal oceans is viewed as a notorious global problem where primary productivity and associated noxious algae blooms are enhanced by anthropogenic nutrient loading (Smith and Schindler 2009). Freshwater fish communities are also widely affected by fisheries that tend to selectively harvest large piscivorous species (Post and others 2002). The interaction between excessive nutrient loading and removal of piscivorous species is often thought to jeopardize many important ecosystem services that less productive ecosystems provide to society (Wilson and Carpenter 1999). Ironically, these human impacts may increase carbon fixation and burial in lakes and reservoirs and thus increase regional capacity to sequester atmospheric $\mathrm{CO}_{2}$. Although the effects of fish and fisheries in pelagic marine food webs is more poorly understood, evidence is accumulating (Essington 2010; Steneck 2012) that alteration of top predator abundances may be linked to carbon sequestration in the sea via effects on the biological pump. Many harvested fish are also highly migratory and, like whales, transport substantial amount of nutrients and organic matter across ecosystem boundaries, in some cases increasing carbon fixation in receiving ecosystems (Naiman and others 2002) and releasing carbon in others (Holtgrieve and Schindler 2011). The management of most industrialized marine fisheries is tending towards avoiding serial depletion of top predators (Worm and others 2009), which could limit the ocean's ability to sequester carbon. Thus, in freshwater and marine ecosystems, managing animals to enhance carbon sequestration may be in direct conflict with maintaining other valued ecosystem functions and services. So, the role of animals in a future world is a double-edged sword. In some cases moving forward with current plans to manage ecosystems without taking the impact of animals into account might cause projects to overestimate the storage returns of a management activity. Alternatively, opportunities exist to use the multiplying indirect effect of animals to allow them to play a positive role in $\mathrm{CO}_{2}$ sequestration while providing other services. These tradeoffs need to 
be explicitly quantified and taken into account as strategies for carbon management unfold. Consideration of animal management within a multiple-objective framework that includes carbon balance as an objective can provide a basis for identifying additional, cost-effective $\mathrm{CO}_{2}$ mitigation wedges (Pacala and Sokolow 2004).

\section{SUMMARY}

Our synthesis offers plausible first approximations merely to encourage further evaluations of animal effects in support of managing carbon dynamics. Where, when, and how animals are important drivers and mediators of carbon storage and exchange still needs to be comprehensively determined to derive a broader, quantitative understanding of their roles. Efforts that have begun to explore animal effects have provided fresh insights about mechanisms that mediate local and regional carbon cycling. Further examination may reveal altogether new insights about ways to manage animal abundances that may lead to value-added situations. This is because management to sequester carbon is often the choice that promotes greater sustainable use and production (e.g., Serengeti grazers, overgrazed grasslands, sea otters and kelp forests, mixed-species forestry to minimize pest impacts on productivity). For this reason, land-use management, and management of key animal species or food webs in ecosystems, may offer opportunities for critical early action enabling policy makers to significantly reduce emissions within the context of local and regional carbon budgets. Management of regional animal effects may also scale up substantially across the globe and thus contribute new options in a global climate change mitigation portfolio (Fig. 2).

\section{ACKNOWLEDGEMENTS}

This paper resulted from the Yale Climate and Energy Institute (YCEI) 2012 conference and workshop "Managing species for regulating the carbon cycle". We thank YCEI for its sponsorship and funding. Regular and OPUS grants from US National Science Foundation, grants from the UK Natural Environmental Research Council and UK Biotechnology and Biological Sciences Research Council, and funding from the Nippon Foundation - UBC Nereus Program, also supported our work.

\section{REFERENCES}

Atkinson A, Siegel V, Pakhomov E, Rothery P. 2004. Long-term decline in krill stock and increase in salps within the Southern Ocean. Nature 432:100-03.

Atwood TB, Hammill E, Greig HS, Kratina P, Shurin JB, Srivastava DS, Richardson JS. 2013. Predator-induced reduction of freshwater carbon dioxide emissions. Nature Geosci 6:191-94.

Ballantyne AP, Alden CB, Miller JB, Tans P, White, JWC. 2012. Increase in observe net carbon dioxide uptake by land and oceans over the past 50 years. Nature 488:70-72.

Beaugrand G, Edwards M, Legendre L. 2010. Marine biodiversity, ecosystem functioning, and carbon cycles. Proc Natl Acad Sci USA 107:10120-124.

Broecker WS, Takahashi T, Simpson HJ, Peng T-H. 1979. Fate of fossil fuel carbon dioxide and the global carbon budget. Science 206: 409-18.

Brodie JF, Gibbs HK. 2005. Bushmeat hunting as climate threat. Science 326:364-65. 
Canadian Forest Service. 2005. State of Canada's forests 2004-2005: Boreal forest. Government of Canada Publications.

Conant, RT, Ryan MG, Ågren G, Birge H, Davidson EA, Eliasson PE, Evans SE, Frey SD, Giardina CP, Hopkins FM, Hyvönen R, Kirschbaum MU, Lavallee JM, Leifel J, Parton WJ, Steinweg JM, Wallenstein MD, Wetterstedt JAM, Bradford MA. 2011. Temperature and soil organic matter decomposition rates - synthesis of current knowledge and a way forward. Global Change Biol 17: 3392-3404.

Cooper CA, Whittamore JM, Wilson RW. 2010. Ca(2+)-driven intestinal HCO(3)(-) secretion and $\mathrm{CaCO}(3)$ precipitation in the European flounder in vivo: influences on acid-base regulation and blood gas transport. Am J Physiol 298: R870-R876.

Crowther TW, Boddy L, Jones TH. 2012. Functional and ecological consequences of saprophytic fungal-grazer interactions. The ISME Journal 6:1992-2001.

de Vries FT, Thébault E, Liiri M, Birkhofer K, Tsiafouli MA, Bjørnlund L, Jørgensen HB, Brady MV, Christensen S, de Ruiter PC, d'Hertefeldt T., Frouz J, Hedlund K, Hemerik L, Hol WHG, Hotes S, Mortimer SR, Setälä H, Sgardelis SP, Uteseny K, van der Putten W, Wolters V, Bardgett RD. 2013. Soil food web properties explain ecosystem services across European land use systems. Proc Nat Acad Sci USA doi: 10.1073/pnas.1305198110

Dlugokencky EJ, Nisbet EG, Fisher R, Lowry D. 2011. Global atmospheric methane: budget changes and dangers. Phil T R Soc A 369: 2058-72.

Doughty CE, Wolf A, Malhi Y. 2013. The legacy of the Pleistocene megafauna extinctions on nutrient availability in Amazonia. Nature Geosci doi:10.1038/ngeo1895.

Dulal HB, Shah KU, Sapkota U. 2012. Reducing emissions from deforestation and forest degradation (REDD) projects: lessons for future policy design and implementation. Int J Sust Dev World 19:116-29.

Dymond, CC, Nielsen ET, Stinson G, Porter K, MacLean DA, Gray DR, Campagna M, Kurz, WA. 2010. Future spruce budworm outbreak may create a carbon source in eastern Canadian forests. Ecosystems 13: 917-31.

Essington T. 2010. Trophic cascades in open ocean ecosystems. In: Terborgh J, Estes JA, Eds. Trophic cascades. Washington DC: Island Press. p 91-105.

Estes JA, Terborgh J, Brashares JS, Power ME, Berger J, Bond WJ, Carpenter SR, Essignton TE, Holt RD, Jackson JBC, Marquis RJ, Oksanen L, Oksanen T, Paine RT, Pikitch EK, Ripple WJ, Sandin SA, Scheffer M, Schoener TW, Shurin JB, Sinclair ARE, Soulé ME, Virtanen R., Wardle DA. 2011. Trophic downgrading of planet Earth. Science 333:301-6.

Falkowski P, Scholes RJ, Boyle E, Canadell J, Canfield D. Elser J. Gruber N, Hibbard K. Högberg P. Linder S, Mackenzie FT, Moore III B, Pedersen T, Rosenthal Y, Seitzinger S, Smetacek V, Steffen W. 2000. The global carbon cycle: a test of our knowledge of Earth as system. Science 290:291-96.

Hawlena D, Schmitz OJ. 2010. Herbivore physiological response to predation risk and implications for ecosystem nutrient dynamics. Proc Nat Acad Sci USA 107:15503-507.

Hawlena D, Strickland MS, Bradford MA, Schmitz OJ. 2012. Fear of predation slows litter decomposition. Science 336:1434-37.

Hicke JA, Allen CD, Desai AR, Dietze MC, Hall RJ, Hogg EH, Kashian DM, Moore, D, Raffa KF, Sturrock RN, Vogelmann J. 2011. Effects of biotic disturbance on forest carbon cycling in the United States and Canada. Global Change Biol 18:7-34. 
Holdo RM, Sinclair ARE, Dobson AP, Metger KL, Bolker BM, Ritchie ME, Holt RD. 2009. A disease-mediated trophic cascade in the Serengeti and its implications for ecosystem C. PLoS Biol 7:e1000210.

Holtgrieve GW, Schindler DE. 2011. Marine-derived nutrients, bioturbation, and ecosystem metabolism: reconsidering the role of salmon in streams. Ecology 92:373-85.

Houghton RA. 2007. Balancing the global carbon budget. Annu Rev Earth Planet Sci 35:313-47.

Houghton RA, Hall F, Goetz SJ. 2009. Importance of biomass in the global carbon cycle. J Geophys Res114: G00E03.

Jobbágy EG, Jackson RB. 2000. The vertical distribution of organic carbon and its relation to climate and vegetation. Ecol Appl 10:423-36.

Kanwisher JW, Ridgway SH. 1983. The physiological ecology of whales and porpoises. Scientific American 248:102-8.

Kasischke ES, Christensen NL Jr, Stocks BJ. 1995. Fire, global warming and carbon balance of boreal forests. Ecol Appl 5:437-51.

Knoll, LB, Vanni MJ, Renwick WH, Dittman EK, Gephart JA. 2013. Temperate reservoirs are large carbon sinks and small $\mathrm{CO}_{2}$ sources: results from high-resolution carbon budgets. Global Biogeochemical Cycles 27:52-64.

Körner C. 2003. Slow in, rapid out - carbon flux studies and Kyoto targets. Science 300:1242-43.

Kurz WA, Dymond CC, Stinson G, Rampley GJ, Neilson ET, Carroll AL, Ebata T, Safranyik L. 2008a. Mountain pine beetle and forest carbon feedback to climate change Nature 452:987-90.

Kurz WA, Stinson G, Rampley GJ, Dymond CC, Neilson ET. 2008b. Risk of natural disturbances makes future contribution of Canada's forests to the global carbon cycle highly uncertain. Proc Nat Acad Sci USA 105:1551-55.

Lebrato M, Iglesias-Rodriguez D, Feely RA, Greeley D, Jones DOB, Suarez-Bosche N, Lampitt RS, Cartes JE, Green DRH, Baker B. 2010. Global contribution of echinoderms to the marine carbon cycle: $\mathrm{CaCO} 3$ budget and benthic compartments. Ecol Monogr 80:441-67.

Lavery TJ, Roundnew B, Gill P, Seymour J. Seuront L., Johnson G, Mitchell JG, Smetacek V. 2010. Iron defecation by sperm whales stimulates carbon export in the Southern Ocean. Proc Royal Soc London (B) 277:3527-31.

LeQuéré C, Raupach MR, Canadell JG, Marland G, Bopp L, Ciais P, Conway TJ, Doney SC, Feely RA, Foster P, Friedlingsten P, Gurney K, Houghton RA, Levy PA, Lomas MR, Majkut J, Metzel N, Ometto JP, Peters GP, Prentice IC, Randerson JT, Running SW, Sarmiento JL, Schuster U, Sitch S., Takahashi T, Viovy N, van der Werf GR, Woodward FI. 2009. Trends in the sources and sinks of carbon dioxide. Nature Geosci 2:831-36.

Lubbers IM, van Groenigen KJ, Fonte SJ, Six J, Brussaard L, van Groenigen JW. Greenhouse-gas emissions from soils increased by earthworms. Nature Climate Change 3:187-94.

Mahecha MD, Reichstein M, Carvalhais N, Lasslop G, Lamge H, Snevirante SI, Vargas R, Ammann C, Arain MA, Cescatti A, Janssens IA, Migliavacca M, Montagnini L, Richardson AD. 2010. Global convergence in the temperature sensitivity of respiration at the ecosystem level. Science 329:838-40.

McLaren BE, Peterson RO. 1994. Wolves, moose, and tree rings on Isle Royale. Science 266:1555- 58.

Medvigy D, Clark KL, Skowronski NS, Schäfer KVR. 2012. Simulated impacts of insect defoliation on forest carbon dynamics. Environ Res Lett 7: article 045703.

Naiman RJ, Bilby RE, Schindler DE, Helfield JM. 2002. Pacific salmon, nutrients, and the dynamics of freshwater and riparian ecosystems. Ecosystems 5:399-417. 
Nicol S. Bowie A, Jarman S, Lannuzel D, Meiners KM, Van Der Merve P. 2010. Southern Ocean iron fertilization by baleen whales and Antarctic krill. Fish and Fisheries 11:203-9.

Pacala S, Sokolow R. 2004. Stabilization wedges: solving the climate problem for the next 50 years with current technologies. Science 305:968-972.

Pan Y, Birdsey RA, Fang J, Houghton R, Kauppi PE, Kurz WE, Phillips OL, Shvidenko A, Lewis SL, Canadell JG, Ciais P, Jackson RB, Pacala SW, McGuire AD, Piao S, Rautianen A, Sitch S, Hayes D. 2011. A large and persistent carbon sink in the world's forests. Science 333:988-93.

Pastor J, Naiman RT, Dewey B, McInnes P. 1988. Moose, microbes and the boreal forest. BioScience 38:770-77.

Perry CT, Salter MA, Harborne AR, Crowley SF, Jelks HL, Wilson RW. 2011. Fish as major carbonate mud producers and missing components of the tropical carbonate factory. Proc Nat Acad Sci USA 108:3865-69.

Peters GP, Marland G, Le Quéré C, Boden T, Canadell JP, Raupach MR. 2012.

CORRESPONDENCE: Rapid growth in CO2 emissions after the 2008-2009 global financial crisis. Nature Climate Change 2:2-4.

Post JR, Sullivan M, Cox S, Lester NP, Walters CJ, Parkinson EA, Paul AJ, Jackson L, Shuter BJ. 2002. Canada's recreational fisheries: the invisible collapse? Fisheries 27:6-17.

Post WM, Peng T-H, Emanuel WR, King AW, Dale VH, DeAngelis DL. 1990. The global carbon cycle. American Scientist 78:310-26.

Revell R, Suess HE. 1957. Carbon dioxide exchange between atmosphere and ocean and the question of an increase in atmospheric CO2 during the past decades. Tellus 9:18-27.

Ripple WJ, Rooney TP, Beschta RL. 2010 Large predators, deer and trophic cascades in boreal and temperate ecosystems. In: Terborgh J, Estes JA, Eds. Trophic cascades. Washington DC: Island Press. p 141-62.

Ritchie ME, Eby SL, Mayemba EP. 2013. Environmental contexts of grazing impacts on soil organic carbon in the Serengeti. PLoS (in review).

Robison BH, Reisenbichler KR, Sherlock RE. 2005. Giant larvacean houses: rapid carbon transport to the deep sea floor. Science 308:1609-11.

Roman, J, McCarthy, JJ. 2010. The whale pump: marine mammals enhance primary productivity in a coastal basin. PLoS ONE 5: e13255.

Sabine CL, Feeley RA, Gruber N, Key RM, Lee K, Bullister JL, Wanninkhof R, Wong CS, Wallace DWR, Tilbrook B, Millero FJ, Peng T-H, Kozyr A, Onon T, Rios AF. 2004. The oceanic sink for anthropogenic $\mathrm{CO}_{2}$. Science 305: 367-71.

Sarmiento JL, Gruber N. 2002. Sinks for anthropogenic carbon. Physics Today 55: 30-36.

Schindler DE, Carpenter SR, Cole JJ, Kitchell JF, Pace ML. 1997. Influence of food web structure on carbon exchange between lakes and the atmosphere. Science 277: 248-51.

Schmidt MWI, Torn MS, Abiven S, Dittmar T, Guggenberger G, Janssens IA, Kleber M, KögelKnabner I, Lehman J, Manning DAC, Nannipieri P, Rasse DP, Weiner S, Trumbore SE. 2011. Persistence of soil organic matter as an ecosystem property. Nature 478:49-56.

Schmitz OJ, Post E, Burns CE, Johnston KM. 2003. Ecosystem responses to global climate change: moving beyond color-mapping. BioScience 53: 1199-1205.

Schmitz OJ, Hawlena D, Trussell GR. 2010. Predator control of ecosystem nutrient dynamics. Ecol Letts 13: 1199-1209.

Schuur E, Abbott B. 2011. High risk of permafrost thaw. Nature 480: 32-33.

Smetacek V, Assmy P, Henjes J. 2004. The role of grazing in structuring Southern Ocean pelagic ecosystems and biogeochemical cycles. Antarctic Science 16:541-558. 
Smetacek V, Klaas C, Strass VH, Assmy P, Montresor M, Cisewski B, Savoye N, Webb A, d'Ovidio F, Arrieta JM, Bathmann U, Bellerby R, Berg GM, Croot P, Gonzalez S, Henjes J, Herndl GH, Hoffmann LJ, Leach H, Losch M, Mills MM, Neill C, Peeken I, Röttgers R, Sachs O, Sauter E, Schmidt MM, Schwarz J, Terbrüggen A, Wolf-Gladrow D. 2012. Depp carbon

Smith VH, Schindler DW. 2009. Eutrophication science: where do we go from here? Trends Ecol Evol 24: 201-7.

Steneck RS. 2010. Apex predators and trophic cascades in large marine ecosystems: Learning from serendipity. Proc Nat Acad Sci USA 109: 7953-54.

Strickland MS, Hawlena D, Reese A, Bradford MA, Schmitz OJ. 2013. Trophic cascade alters ecosystem carbon exchange. Proc Nat Acad Sci USA in press.

Tanentzap AJ, Coomes DA. 2012. Carbon storage in terrestrial ecosystems: do browsing and grazing herbivores matter? Biol Reviews 87: 72-95.

Tarnocai C, Canadell JG, Schuur EAG, Kuhry P, Mazhitova G, Zimov S. 2009. Soil organic carbon pools in the northern circumpolar permafrost region. Global Biogeochem. Cycles 23:GB2023.

Thomas, C.D., Anderson BJ, Mioilanen A, Eigenbrod F, Heinemeyer A, Quaife T, Roy DB, Gillings S, Armsworth PR, Gaston KJ. 2012. Reconciling biodiversity and carbon conservation. Ecol Lett 16 S1:39-47.

Tranvik LJ, Downing JA, Cottner JB, Loiselle SA, Striegl RG, Ballatore TJ, Dillon P, Finlay K, Knoll LB, Kortelainen PL, Kutser T, Larsen S. Laurion I, Leech DM, McCallister S.L., McKnight DM, Melack JM, Overholt E, Porter JA, Prairie Y, Renwick WH, Rolando F, Sherman BS, Schindler DW, Sobeck S, Tremblay A, Vanni MJ, Verschoor AM, Von Wachtenfeldt E, Weyhenmeyer GA. 2009. Lakes and reservoirs as regulators of carbon cycling and climate. Limnol. Oceanogr. 54:2298-2314.

US Environmental Protection Agency. Draft inventory of U.S. greenhouse gas emissions and sinks. (National Service Center for Environmental Publications, 2013) http://www.epa.gov/climatechange/ghgemissions/usinventoryreport.html

Vanni MJ. 2002. Nutrient cycling by animals in freshwater ecosystems. Annu Rev Ecol Syst 33: 341-70.

Vanni MJ, Renwick WH, Bowling AM, Horgan MJ, Christian AD. 2011. Nutrient stoichiometry of linked catchment-lake systems along a gradient of land use. Freshwater Biol 56:791-811.

Venter O, Koh L-P. 2012. Reducing emissions from deforestation and forest degradation (REDD+): game changer or just another quick fix? Ann NY Acad Sci 1249:137-50.

Wardle DA, Bellingham PJ, Fukami T, Bonne KI. 2012. Soil-mediated indirect impacts of an invasive predator on plant growth. Biol Lett 8:574-77.

Ware JR, Smith SV, Reaka-Kudla ML. 1992. Coral reefs: sources or sinks of atmospheric $\mathrm{CO}_{2}$ ? Coral Reefs 11:127-30.

Whittamore JM, Cooper CA, Wilson RW. 2010. $\mathrm{HCO}_{3}{ }^{-}$secretion and $\mathrm{CaCO}_{3}$ precipitation play major roles in intestinal water absorption in marine teleost fish in vivo. Am J Physiol 298: R877-R886.

Wilmers CC, Estes JA, Edwards M, Laidre KL, Konar B. 2012. Do trophic cascades affect the storage and flux of atmospheric carbon? An analysis for sea otters and kelp forests. Frontiers Ecol Env 10:409-15.

Wilson MA, Carpenter SR. 1999. Economic valuation of freshwater ecosystem services in the United States: 1971-1997. Ecol Appl 9:772-83. 
Wilson RW, Millero FJ, Taylor JR, Walsh PJ, Christensen V, Jennings S, Grosell M. 2009. Contribution of fish to the marine inorganic carbon cycle. Science 323: 359-62.

Woodwell GM, Whitaker RH, Reiners WA, Likens GE, Delwich CC, Botkin DB. 1978. Biota and the world carbon budget. Science 199:141-46.

Woosley RJ, Millero FJ, Grosell M. 2012. The solubility of fish-produced high magnesium calcite in seawater. J Geophysical Sciences 117:C1048.

Worm B, Hilborn R, Baum JK, Branch TA, Collie JS, Costello C, Fogarty MJ, Fulton EA, Hutchings JA, Jennings S, Jensen OP, Lotzke HK, Mace PM, McClanahan TR, Minto C, Palumbi SR, Parma AM, Ricard D, Rosenberg AA, Watson R, Zeller D. 2009. Rebuilding global fisheries. Science 325:578-85.

Zimov SA, Schuur EG, Chapin FS III. 2006. Permafrost and the global carbon budget. Science 312:1612-13.

Zimov NS, Zimov SA, Zimova AE, Zimova GM, Chpryinin VI, Chapin FS III. 2009. Carbon storage in permafrost and soils of the mammoth tundra-steppe biome: role in the global carbon budget. Geophys Res Lett 36:L02502. 
Table 1. Magnitude of carbon exchanges or storage in different ecosystems with and without animal species. Carbon can be taken up in plant biomass (NPP), stored in plant biomass (storage), soils or sediment (burial) or escape to the atmosphere (release). Differential quantifies the net difference in carbon exchange between when animals are present or in high abundance vs. absent or in low abundance. Values in red indicate release to the atmosphere, values in black indicate uptake into terrestrial or aquatic reservoirs.

\begin{tabular}{|c|c|c|c|c|}
\hline Species & $\begin{array}{l}\text { Low Density } \\
\text { or absence } \\
\left(\mathrm{Tg} \mathrm{C} \mathrm{yr}^{-1}\right)\end{array}$ & 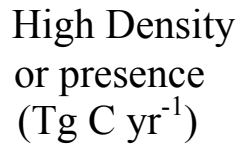 & 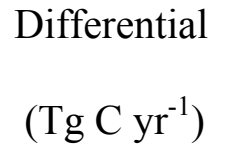 & $\begin{array}{l}\text { Extent of region } \\
\qquad\left(\mathrm{Km}^{2}\right)\end{array}$ \\
\hline \multicolumn{5}{|c|}{ Terrestrial } \\
\hline Large mammals & $183-1825$ & $\sim 0$ & $183-1825$ & $\begin{array}{c}1.0 \times 10^{6} \\
\text { Arctic yedoma }\end{array}$ \\
\hline Moose & $548-656$ & $689-722$ & $66-141$ & $\begin{array}{l}1.89 \times 10^{6} \\
\text { North American boreal forest }\end{array}$ \\
\hline $\begin{array}{l}\text { Mountain Pine } \\
\text { Beetle }\end{array}$ & 0.6 & 15.8 & 16.4 & $\begin{array}{c}7.4 \times 10^{4} \\
\text { Interior British Columbia }\end{array}$ \\
\hline Wildebeest & 5.0 & 0.9 & 5.9 & $\begin{array}{l}2.5 \times 10^{4} \\
\text { Serengetti }\end{array}$ \\
\hline \multicolumn{5}{|c|}{ Marine } \\
\hline Fish & & $40-110$ & & $\begin{array}{l}3.0 \times 10^{8} \\
\text { Global, pelagic }\end{array}$ \\
\hline \multirow[t]{4}{*}{ Echinoderms } & & 93 & & $\begin{array}{l}1.0 \times 10^{7} \\
\text { Global, shelf }\end{array}$ \\
\hline & & 7.8 & & $\begin{array}{c}3.2 \times 10^{7} \\
\text { Global, slopes }\end{array}$ \\
\hline & & 1.9 & & $2.9 \times 10^{8}$ \\
\hline & & & & Global, abyssal \\
\hline Sea Otter & $0.3--0.9$ & $1.2-2.2$ & $0.9-1.3$ & $\begin{array}{l}1.2 \times 10^{4} \\
\text { North Pacific inshore }\end{array}$ \\
\hline
\end{tabular}




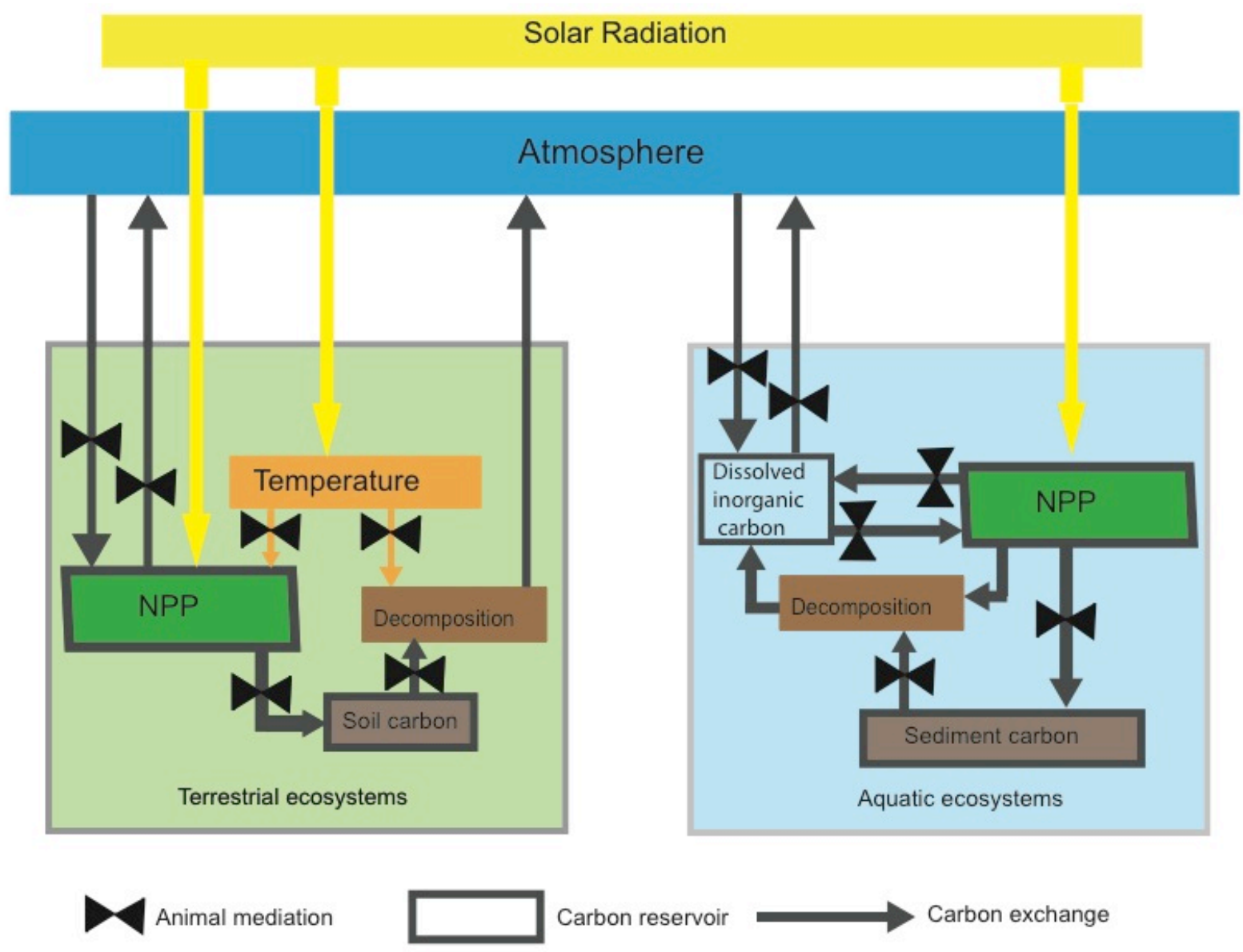

Figure 1. A schematic of how animals can influence carbon exchange and storage in terrestrial and aquatic ecosystems. This depicts exchanges between terrestrial and atmospheric reservoirs and aquatic and atmospheric reservoirs. In terrestrial ecosystems, animals can mediate uptake and release of $\mathrm{CO}_{2}$ (and hence NPP) by influencing the amount of plant biomass present in an ecosystem. By killing live biomass in NPP, they can promote wildfires that release $\mathrm{CO}_{2}$ to the atmosphere. Animals can influence biophysical conditions such as temperature through destruction of vegetation or trampling that in turn alter rates of NPP, decomposition and wildfires and ultimate release of $\mathrm{CO}_{2}$ and $\mathrm{CH}_{4}$ to the atmosphere. Animals can determine the amount of organic matter biomass and chemical elemental quality of that biomass in NPP that enters the soil pool. Control over organic matter chemical quality influences the rates of organic matter decomposition and $\mathrm{CO}_{2}$ release. In aquatic systems, animals can determine levels of inorganic carbon in dissolved form (DIC) by producing it from physiological processes. Production of DIC can influence surface level $\mathrm{pH}$ that influences $\mathrm{CO}_{2}$ exchange between surface waters and the atmosphere. Animals can mediate uptake and release of $\mathrm{CO}_{2}$ into plant biomass (and hence NPP) by influencing the amount of plant biomass present in an ecosystem. They can mediate the amount of organic $\mathrm{C}$ that is transported to sediment reservoirs via physical circulation processes. By disturbing sediments (bioturbation) they can determine the amount of sediment organic $\mathrm{C}$ that is released to the water column to be decomposed and hence released to the atmosphere. 


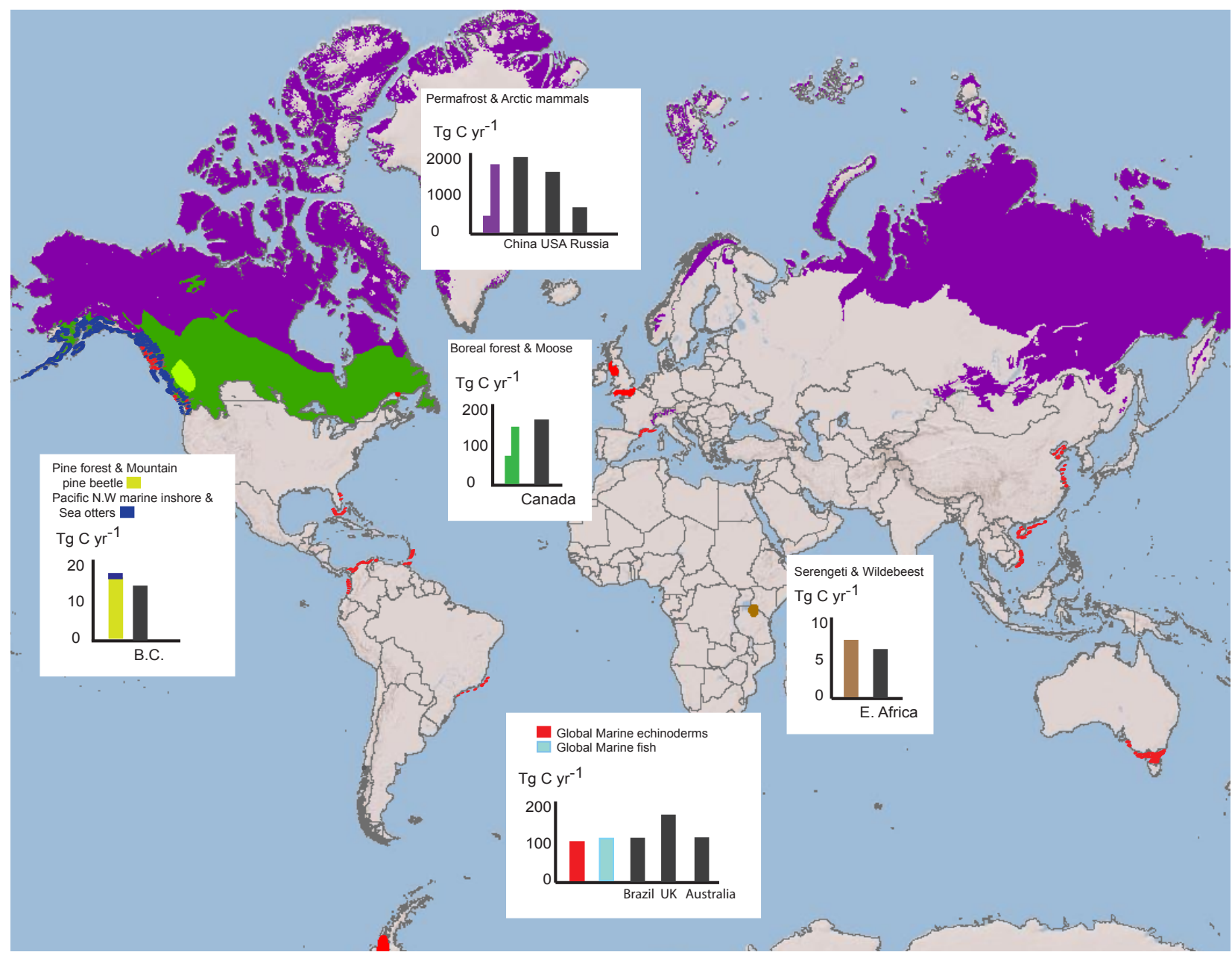

Figure 2. Quantification of animal contributions to regional carbon budgets and comparison with anthropogenic fossil fuel emissions from the same regions. The figure illustrates that the magnitudes of carbon uptake or release due to effects of individual animal species or groups of animals within their respective regional ecosystems can rival the magnitudes of carbon released in $\mathrm{CO}_{2}$ through anthropogenic fossil fuel emissions including solid and liquid fossil fuel burning, gas flaring, and cement production. Split bars for particular ecosystems show estimated ranges of flux estimates. Data for anthropogenic releases were obtained from http://cdiac.ornl.gov/trends/emis/tre coun.html for global countries and from http://www.ec.gc.ca/publications/default.asp?lang=En\&n=3CD345DC-

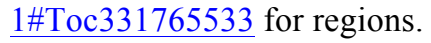




\begin{abstract}
APPENDiX A
Information on the sources and calculations for the estimated carbon fluxes due to animal presence presented in Table 1.
\end{abstract}

\title{
Estimation of Arctic grazing herbivore effects
}

Zimov and others (2006) state that Yedoma permafrost covers $10^{6} \mathrm{~km}^{2}$. Using laboratory incubations of thawed soil to measure long term (several year) respiratory release of $\mathrm{CO}_{2}$, they found that soils emitted 0.5 to $5 \mathrm{~g} \mathrm{C} \mathrm{m}^{3} \mathrm{~d}^{-1}$. Assuming a $1 \mathrm{~m}$ deep active layer (Zimov and others 2006), we estimate that Yedoma could potentially release about $183-1825 \mathrm{Tg} C$ over the entire $10^{6} \mathrm{~km}^{2}$ Yedoma region.

\section{Estimation of Moose effects}

Data used to estimate moose contributions to whole ecosystem carbon cycling were obtained from experimental research conducted in Isle Royale Michigan, USA. Moose influence ecosystem carbon uptake through browsing, by priming soil microbial activity through fecal deposition, and through direct respiration (Pastor and others 1992).

Net primary productivity (NPP) of trees in areas excluding moose amounts to $8000 \mathrm{~kg} \mathrm{C}$ $\mathrm{ha}^{-1} \mathrm{yr}^{-1}$ or $8 \times 10^{8} \mathrm{~g} \mathrm{C} \mathrm{km}^{-2} \mathrm{yr}^{-1}$ (McInnes and others 1992). Comparisons of impacts of moose at varying densities also reveals that NPP declines by between 700 and $1500 \mathrm{~kg} \mathrm{C} \mathrm{ha}^{-1} \mathrm{yr}^{-1}$ per unit of moose (McInnes and others 1992). Therefore, under higher moose density $\left(\sim 1.5\right.$ moose $\left.\mathrm{km}^{-2}\right)$, NPP ranges between $5.8 \times 10^{8}-6.95 \times 10^{8} \mathrm{~g} \mathrm{C} \mathrm{km}^{-2} \mathrm{yr}^{-1}$, and under low density $\left(\sim 0.5\right.$ moose $\left.\mathrm{km}^{-2}\right)$, NPP ranges between $7.25 \times 10^{8}-7.65 \times 10^{8} \mathrm{~g} \mathrm{C} \mathrm{km}^{-2} \mathrm{yr}^{-1}$. (These moose densities fall at the low end of the density range of 0.4 to 9.3 moose $\mathrm{km}^{2}$ reported for the boreal forest globally [Feldhamer and others 2003]). The boreal forest ecosystem in Canada covers an area of $2.54 \times 10^{6}$ $\mathrm{km}^{2}$, of which $1.89 \times 10^{6} \mathrm{~km}^{2}$ is $90-100 \%$ intact (Canadian Forest Service 2005. Using this conservative estimate of intact forest, and assuming wood biomass contains $50 \%$ carbon (Jain and

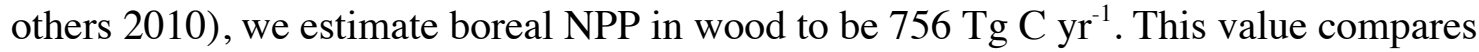

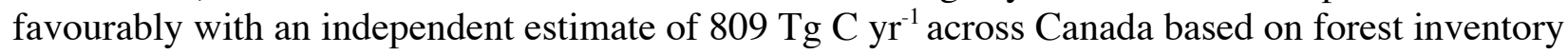
data from managed forests (Stinson and others 2011).

We estimated that NPP for the $1.89 \times 10^{6} \mathrm{~km}^{2}$ intact boreal in Canada to be $548{\mathrm{Tg} \mathrm{C} \mathrm{yr}^{-1}-}^{-}$

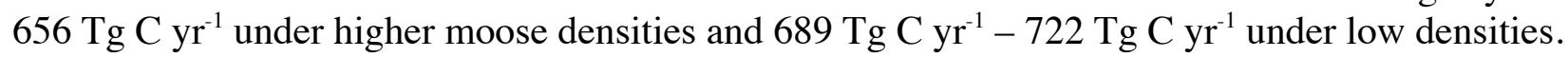
This leads to a difference of $\sim 66 \mathrm{Tg} \mathrm{C} \mathrm{yr}^{-1}-141 \mathrm{Tg} \mathrm{C} \mathrm{yr}^{-1}$. This estimate of carbon uptake does not account for potential carbon release through heterotrophic respiration (moose and microbes).

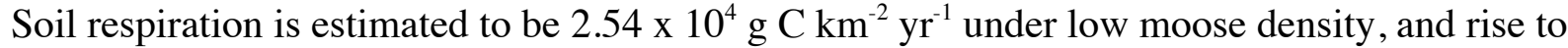
$3.43 \times 10^{4} \mathrm{~g} \mathrm{C} \mathrm{km}^{-2} \mathrm{yr}^{-1}$ (Pastor and others 1993). Moose respiration varies seasonally being higher in spring, summer and fall than in winter (Regelin and others 1985). We used spring, summer and fall respiration as a liberal measure of $\mathrm{C}$ release. Moose metabolic rate during this time is $552 \mathrm{KJ} \mathrm{kg}^{-0.75}$ (Regelin and others 1985). Assuming an individual moose has a body mass of $359 \mathrm{~kg}$ (Regelin and others 1985), we estimate a respiration rate of $4.55 \times 10^{4} \mathrm{KJ}_{\text {individual }}{ }^{-1} \mathrm{~d}^{-}$ ${ }^{1}$, or $1.1 \times 10^{3} \mathrm{~g} \mathrm{C}$ individual $^{-1} \mathrm{~d}^{-1}$, assuming $41 \mathrm{KJ}\left(\mathrm{g} \mathrm{C}^{-1}\right.$. Under low moose densities on Isle Royale, annual (365 d) respiratory release of $\mathrm{C}$ is $3.73 \times 10^{5} \mathrm{~g} \mathrm{C} \mathrm{km}^{-2} \mathrm{yr}^{-1}$ and rises to $1.73 \times 10^{6} \mathrm{~g} \mathrm{C}$ $\mathrm{km}^{-2} \mathrm{yr}^{-1}$ under high moose densities. Collectively, soil and moose respiration is orders of magnitude less than tree NPP. Thus, effects of moose on carbon exchange is dominated by tree NPP. 


\section{Estimation of Mountain Pine Beetle effects}

Estimates are based on simulations of pine beetle effects in a $75,000 \mathrm{~km}^{2}$ area within interior British Columbia, Canada that was subject to a pine beetle outbreak (Kurz and others 2008). Average annual emissions were estimated from data presented in Figure 4 (Kurz and others 2008) for the 17-year period after the 2003 outbreak for the control scenario (low beetle abundance) and the beetle scenario (beetle outbreak).

\section{Estimation of Wildebeest effects}

Estimates of carbon flux for the $25,000 \mathrm{~km}^{2}$ Serengeti savanna ecosystem under historically low wildebeest density (250,000 animals in 1960) and currently high wildebeest density $(1,250,000$ animals in 1990's) were obtained from Fig. 5B in Holdo and others (2009). These values do not account for direct release from the animals themselves. Based on methane release in cattle (in $\mathrm{CO}_{2}$ equivalents [Dlugokencky and others 2011]), we estimated that per capita release for a 100 $\mathrm{kg}$ individual would be $2.75 \times 10^{5} \mathrm{~g} \mathrm{C} \mathrm{yr}^{-1}$. Emissions directly from animals (when per capita effects were scaled to low and high population densities: $6.8 \times 10^{10}-3.3 \times 10^{11} \mathrm{~g} \mathrm{C} \mathrm{yr}^{-1}$ ) were $1-2$ orders of magnitude less than the whole ecosystem level effects.

\section{Estimation of marine fish and marine echinoderm effects}

Estimates of marine fish $\mathrm{CaCO}_{3}$ production were obtained from Fig. 1 in Wilson and others (2009). Estimates of marine echinoderm $\mathrm{CaCO}_{3}$ production were obtained from Table 5 in Lebrato and others (2010).

\section{Estimation of Sea Otter effects}

Estimates of sea otter contributions to marine carbon flux were obtained by scaling per $\mathrm{m}^{2}$ estimates of net primary productivity presented in Table 1 in Wilmers and others 2012) to the entire $12,000 \mathrm{~km}^{2}$ region occupied by sea otters.

\section{REFERENCES}

Canadian Forest Service. State of the Canada's forests 2004-2005: Boreal forest. Government of Canada Publications (2005).

Dlugokencky EJ, Nisbet EG, Fisher R, Lowry D. 2011. Global atmospheric methane: budget changes and dangers. Phil T R Soc A 369: 2058-72.

Feldhamer GA, Thompson BC, Chapman JA (eds). 2003. Wild Mammals of North America: Biology, Management and Conservation (Baltimore: Johns Hopkins University Press).

Jain TB, Graham RT, Adams D. 2010. Carbon concentrations and carbon pool distributions in dry, moist, and cold mid-aged forests of the Rocky Mountains. USDA Forest Service Proceedings RMRS-P-61.

Holdo RM, Sinclair ARE, Dobson AP, Metger KL, Bolker BM, Ritchie ME, Holt RD. 2009. A disease-mediated trophic cascade in the Serengeti and its implications for ecosystem C. PLoS Biol 7:e1000210.

Kurz WA, Dymond CC, Stinson G, Rampley GJ, Neilson ET, Carroll AL, Ebata T, Safranyik L. 2008a. Mountain pine beetle and forest carbon feedback to climate change Nature 452:987-90. Lebrato M, Iglesias-Rodriguez D, Feely RA, Greeley D, Jones DOB, Suarez-Bosche N, Lampitt RS, Cartes JE, Green DRH, Baker B. 2010. Global contribution of echinoderms to the marine carbon cycle: $\mathrm{CaCO} 3$ budget and benthic compartments. Ecol Monogr 80:441-67. 
McInnes PF, Naiman RJ, Pastor J, CohenY. 1992. Effects of moose browing on vegetation and litter of the boreal forest, Isle Royale, Michigan, USA. Ecology 73:2059- 75.

Pastor J, Naiman RT, Dewey B, McInnes P. 1988. Moose, microbes and the boreal forest. BioScience 38:770-77.

Pastor J, Dewey B, Naiman RJ, McInnes PF, Cohen Y. 1993. Moose browing and soil fertility in the boreal forests of Isle Royale National Park. Ecology 74:467-80.

Regelin WL, Schwartz CC, Franzmann AW. 1985. Seasonal energy metabolism of adult moose. J Wildl Manage 49:388-93.

Stinson G, Kurz WA, Smyth CE, Neilson ET, Dymond CC, Metsaranta JM, Boisevenue C, Rampley GJ, Li Q, White TM, Blain D. 2011. An inventory-based analysis of Canada's managed forest carbon dynamics, 1990 to 2008. Global Change Biology 17:2227-44.

Wilmers CC, Estes JA, Edwards M, Laidre KL, Konar B. 2012. Do trophic cascades affect the storage and flux of atmospheric carbon? An analysis for sea otters and kelp forests. Frontiers Ecol Env 10:409-15.

Wilson RW, Millero FJ, Taylor JR, Walsh PJ, Christensen V, Jennings S, Grosell M. 2009. Contribution of fish to the marine inorganic carbon cycle. Science 323: 359-62.

Zimov SA, Schuur EG, Chapin FS III. 2006. Permafrost and the global carbon budget. Science 312:1612-13. 